\title{
Effective Microorganisms in Producing Eco-Enzyme from Food Waste for Wastewater Treatment
}

\author{
Chin Wen Low, Regina Leong Zhi Ling, Swee-Sen Teo* \\ Faculty of Applied Sciences, UCSI University, No.1 Jalan Menara Gading, UCSI Heights, 56000 Cheras, Kuala Lumpur, W. P. \\ Kuala Lumpur, Malaysia \\ E-mail: teoss@ucsiuniversity.edu.my
}

Received: 25 November 2020; Revised: 22 April 2021; Accepted: 29 April 2021

\begin{abstract}
The problem of food wastage is becoming an increasingly worrying topic as the world is heading towards sustainability to preserve the quality and the perseverance of life on Earth. Such food waste is inclusive of fresh fruit and vegetable (FFV) which make up a substantial $60 \%$ of all food wasted around the globe. Hence the purpose of this study is to valorize the FFV waste into eco-enzymes for the purpose of wastewater treatment, as having clean water sources and cleaning greywater and blackwater before discharge back into the environment are an important factors in preserving public health worldwide. Only a total of $1 \%$ of the world's freshwater is accessible for human consumption, therefore it is important to save and recycle this precious resource. The objective of this study was to fully utilize the food waste in wastewater treatment. The production of eco-enzyme is done via the process of fermentation of FFV. In this study, eco-enzymes were generated from waste derived from vegetable-and fruit. The vegetable eco-enzyme was fermented via $S$. cerevisiae for a total of 7 days. The fruit-produced eco-enzyme was fermented with brown sugar for three months with the native bacterial population present within the fruit as the fermentation agent. The eco-enzymes produced were used to treat the water samples collected from Menjalara Lake $\left(3^{\circ} 11^{\prime} 42.2^{\prime \prime} \mathrm{N} 101^{\circ} 37^{\prime} 39.7^{\prime \prime} \mathrm{E}\right)$ and Keroh River $\left(3^{\circ} 12^{\prime} 25.0^{\prime \prime} \mathrm{N} 101^{\circ} 38^{\prime} 27.9^{\prime \prime} \mathrm{E}\right)$. In addition, household rice-rinsed water was obtained from Kajang $\left(3^{\circ} 07^{\prime} 38.0^{\prime \prime} \mathrm{N} 101^{\circ} 51^{\prime} 83.0^{\prime \prime} \mathrm{E}\right)$. After the fermentation, the eco-enzymes solutions were acidic with a pH range of 4.1-5.24, which could be due to the metabolization of carbohydrates into volatile and organic acids. The effectiveness of the eco-enzyme treatments was assessed via measuring $\mathrm{Ca}^{2+}, \mathrm{Na}^{+}, \mathrm{K}^{+}, \mathrm{NO}_{3}{ }^{-}$and $\mathrm{pH}$. It was found that the fruit-produced eco-enzyme was effective in reducing $\mathrm{NO}_{3}^{-}$, in all three water samples. But both the fruit-produced eco-enzyme and vegetable-produced eco-enzyme were not effective in reducing the concentration of $\mathrm{Ca}^{2+}, \mathrm{Na}^{+}$and $\mathrm{K}^{+}$. Further improvements that can be done are the prolonging of treatment duration from five days to 30 days. Other than that, experimentation with different concentrations to reduce the introduction of excess metal ions into the treated water samples.
\end{abstract}

Keywords: eco-enzyme, water quality, food waste, fermentation, wastewater treatment

\section{Introduction}

According to United Nations Sustainable Development Goals (SDGs), food-related issues interconnected with many aspects of the society. Goal 12 in SDGs, emphasis on sustainable consumption and production patterns, which shows that sustainability has become prerequisites in life and environment quality as an unpolluted environment is required for the world. Natural resources play a significant role in earth and assimilate into every aspect of human lives.

Copyright (C2021 Swee-Sen Teo, et al.

DOI: https://doi.org/10.37256/aie.212021726

This is an open-access article distributed under a CC BY license

(Creative Commons Attribution 4.0 International License)

https://creativecommons.org/licenses/by/4.0/ 
They are required for all living organisms to sustain their lives and daily activities. Natural resources can be biotic or abiotic. Biotic resources simply refer to living organisms such as plants and animals while abiotic resources refer to nonliving things such as water, air and minerals that occur naturally in the earth. Both resources play a vital role in shaping the ecosystem and reliant on each other. If one of the sources removed from the ecosystem, the entire ecosystem will be affected including the survival and reproduction of organisms. Nowadays, pollution is catching the eyes of society because pollutions are associated with climate change and its side effects and risks to the living organism are huge and undergoing. In a thriving development, scarcity of natural resources was concerned. The increasing of human population increased the food demand which indirectly raises the production of food waste contributed to the environment. Improper waste management or disposal resulted in environmental pollution which affects the health of the ecosystem and human health problems.

Most of the wastes including food waste were dumped irresponsibly into the landfill or flow into the water bodies. Food waste is a global environmental issue where almost one-third of the food has been throwing as waste. Not only food is lost, but many resources have been wasted for food production including water and land for plantation. Other than that, high food demand increased the amount of waste contributed. Nevertheless, today food waste has become an alternative to replace chemical fertilizers in agriculture. Conversion of food waste into organic fertilizers or feedstocks by composting indeed a way to address food waste dumped in the environment. Moreover, reusing food waste through composting producing eco-enzyme can also use as biogas to produce energy [1]. Eco-enzyme is a term to simplify the different type of enzymes that may be produced within the fermentation media using food wastes.

In Malaysia, 53\% of the rivers' water quality had been classified into class II and class II which are slightly polluted and polluted respectively [2]. This scenario happens are due to industrial development, agricultural activities and improper waste disposal that resulted in water pollution. Waste flow into the water bodies by surface runoffs, the effluent of industrial and sewage discharge. This creates excessive nutrients level and organic matters in the water bodies which affects the life of aquatic organisms and human consumption. Besides, water bodies might contain harmful chemicals or heavy metals not only affects health problems but degrade the water quality. Water is essential to sustain life quality and carry out daily activities, and hence, wastewater treatment is necessary for the production of good water quality. Hence, this study is an attempt to valorize fresh fruits and vegetable (FFV) waste as substrates for eco-enzyme production to treat wastewater. The objective of this study is to produce eco-enzymes from FFV via fermentation as an effort to valorise fresh fruit and vegetable waste. It is also aimed to improve wastewater treatment using eco-enzymes by reducing the impurities within wastewater such as excess calcium $\left(\mathrm{Ca}^{2+}\right)$, potassium $\left(\mathrm{K}^{+}\right)$, sodium $\left(\mathrm{Na}^{+}\right)$and nitrate $\left(\mathrm{NO}_{3}{ }^{-}\right)$as well as observe the changes in $\mathrm{pH}$ of the wastewaters as a more environmentally conscious method of treating wastewater.

\section{FFV wastes}

About 1.3 billion tons of food goes to waste annually across the world, amounting to approximately $33.3 \%$ of all foods produced for human consumption, and half of these food waste comprises fresh fruits and vegetables [3-4]. Food waste can make up to a staggering $60 \%$ of total landfill content [5]. These food wastes left to decompose in the landfill or underground. In Malaysia, the amount of food waste threw was unimaginable. According to an article in New Straits Times, Solid Waste Management and Public Cleansing Corporation (SWCorp) reported that there were about 16,688 tonnes of daily food waste thrown which was sufficient to feed 12 million people [6]. This scenario causes not only food was wasted but all the resources creating the food were also wasted such as land, water, energy, labour, and species. This food waste ended up disposed at landfill, and honestly, the space for these solid wastes was running out. Malaysia had more than 230 landfills and the majority were crude dumping grounds [7-8]. However, the amount of land available will become scarce as more and more open dumping practices occur in most of the landfill in Malaysia. This practice contributed to environmental issues where it can pollute natural resources such as land, water, and air as well as harmful to health.

Food waste contributing $60 \%$ to the landfill where $50 \%$ of them were FFV [4]. When these food wastes dumped to landfill, decomposition happen without access to oxygen because they come in a vast amount. This creates methane as a by-product which is more hazardous than carbon dioxide. Decomposition is the process of breaking down organic matters into simpler organic matter such as carbon dioxide, water and simple sugar. However, decomposition in landfill 
or underground can release greenhouse gases into the atmosphere such as methane because there is limited or no access to oxygen where this process is known as anaerobic decomposition. Methane gas not only emits foul odors but also affecting climate change [9-10] including leachate generated from food waste recycling facilities from 2012, it is urgent to develop an innovative and sustainable disposal strategy that is eco-friendly, yet economically beneficial. In this study, methane production from food waste leachate (FWL). Decomposition with the presence of oxygen is known as aerobic decomposition or composting. Composting is a decomposition process that converts organic waste by microbes into compost which can be used as organic fertilizers or feedstock for agriculture practice. It does not produce methane because microbes that produce methane were inactive with the presence of oxygen. Recently, the composting practice has been a good initiative to society and the environment to minimize the amount of organic waste in the landfills at the same time reduce the emission of methane gas.

Fermentation of organic waste is a type of anaerobic decomposition where the microbes break down the organic waste without oxygen into simpler organic material known as bokashi. Bokashi refers to fermented organic matter where they are less odor than the normal anaerobic decomposition. During the fermentation process, the byproducts produced are molasses and eco-enzyme which can act as the energy source for microbes to undergo fermentation. Ecoenzyme is a complex solution produced from the fermentation process of FFV. It can be used as a multipurpose liquid to serve as organic fertilizer, remove odor, cleansing reagent or treat wastewater [11-12]. Eco-enzyme is natural fertilizers and pesticides which are eco-friendly and biodegradable to replace the chemical fertilizers in the agricultural field. Fermentation of wastes plays a major role in removing environmental wastes which can lead to a safe environment and improve the water quality of natural aquatic ecosystems. The eco-enzymes are potential in treating wastewater especially in the pre-treatment of the organic aquaculture sludge which can enhance the further secondary and tertiary treatment of the organic wastes [13].

\section{Wastewater treatment}

The importance of improving wastewater treatment gains high priority as only 1\% of Earth's freshwater supplies are accessible by humans. Hence, it is crucial new techniques are explored in order to preserve and recycle the freshwater that is consumable by humans [14]. Besides the obvious reason for preserving the invaluable freshwater that humans rely on for survival for future generations, wastewater treatment also plays a key role in maintaining public health [15]. Wastewater is used water where contaminants may come from point sources or non-point sources. Point source can be identified where the contaminants released from a single pipeline such as sewage treatment plant whereas non-point source are the diffuse source where the contaminant sources are harder to identify as they can come from different places such as surface runoffs [16-17]. Untreated wastewater can pose health risks for humans as well as the surrounding environment and ecosystems due to the pollutants [18]. The intensification of agricultural activities has grown over the years to support the elevated demand of crops for human consumption which increases with the human population. From these agricultural activities, comes the use of fertilizers to improve crop yield [19]. Excess nutrient from the fertilizers often leaches into groundwaters to other water bodies which pollute the water body.

Nutrients such as phosphorus, nitrogen and potassium can result in eutrophication which is detrimental to the water bodies in the ecosystem [20-21]. Eutrophication occurs when excessive nutrients and minerals present in the water induced algae over bloom. This can impose serious health effect on aquatic organisms and degrade water quality. Water surface covered with algae can be resulting in blocking sunlight penetration to the water column for aquatic plants and competing for dissolved oxygen between fishes and microbes as microbes need dissolved oxygen for decomposition when the presence of decaying matter. Insufficient dissolved oxygen in the water column can result in the suffocation of fish and disease may occur. Other than that, eutrophication also causes the water to become turbid and unpleasant smell which affects the water quality and restricts water usage for daily activities [22]. Hence, wastewater treatment is necessary to provide a good water quality of the ecosystem, drinking water and ensure the health status of aquatic organisms as well as the public. This study aims to produce eco-enzyme from FFV waste for wastewater treatment goes together with development towards a sustainable future. 


\section{Methodology}

\subsection{Production and testing of eco-enzymes}

The fermentation process was carried out using sample:brown sugar:water (3:1:10) ratio. The eco-enzymes produced were used in an attempt to treat wastewater from 3 different sources which are Menjalara Lake $\left(3^{\circ} 11^{\prime} 42.2^{\prime \prime} \mathrm{N}\right.$ $\left.101^{\circ} 37^{\prime} 39.7^{\prime \prime} \mathrm{E}\right)$, Sungai Keroh $\left(3^{\circ} 12^{\prime} 25.0^{\prime \prime} \mathrm{N} 101^{\circ} 38^{\prime} 27.9^{\prime \prime} \mathrm{E}\right)$ and household rice rinsing water $\left(3^{\circ} 07^{\prime} 38.0^{\prime} \mathrm{N}\right.$ $\left.101^{\circ} 51^{\prime} 83.0^{\prime \prime} \mathrm{E}\right)$. The water samples were first autoclaved to eliminate the native bacterial population within each water sample to ensure that there is no interference with the experimental data. A volume of $1 \mathrm{~m} \ell$ of the fermented solution containing eco-enzymes was added into $50 \mathrm{~m} \ell$ falcon tubes containing $40 \mathrm{~m} \ell$ of each water sources. Water parameters of $\mathrm{Ca}^{2+}, \mathrm{Na}^{+}, \mathrm{K}^{+}$and $\mathrm{NO}_{3}{ }_{3}^{-}$and $\mathrm{pH}$ reading was measured for each tube for a duration of 5 days to observe for changes. The objective of this experiment is to monitor the effect of eco-enzyme in influencing the level of $\mathrm{Ca}^{2+}, \mathrm{Na}^{+}, \mathrm{K}^{+}$and $\mathrm{NO}_{3}{ }^{-}$ in water samples. Baker's yeast, Saccharomyces cerevisiae was chosen to be the organism of choice for eco-enzymes production.

\subsection{Sample treatment with eco-enzyme}

All water samples were treated with eco-enzyme in a ratio of 40:1 (sample:eco-enzyme). Water parameters of $\mathrm{Ca}^{2+}, \mathrm{Na}^{+}, \mathrm{K}^{+}$and $\mathrm{NO}_{3}{ }^{-}$were measured in the unit of parts per million (ppm) for a duration of 5 days using the Horiba LAquatwin water quality probes.

\section{Results and discussion}

The parameters being measured are the concentration of ions such as calcium ions $\left(\mathrm{Ca}^{2+}\right)$, sodium ions $\left(\mathrm{Na}^{+}\right)$, potassium ions $\left(\mathrm{K}^{+}\right)$, nitrate ions $\left(\mathrm{NO}_{3}^{-}\right)$, and the $\mathrm{pH}$ of the water samples. Table 1 shows the locations of the sources of water being sampled, the reason for the sampling and the condition(s) of the sources when being sampled.

Table 1. Observation and justification on water sampling sites

\begin{tabular}{|c|c|c|}
\hline Locations & Condition(s) & Reason(s) for sampling \\
\hline $\begin{array}{c}\text { Menjalara Lake, Kepong } \\
\left(3^{\circ} 11^{\prime} 42.2^{\prime} \mathrm{N} 101^{\circ} 37 ’ 39.7 ’ \mathrm{E}\right)\end{array}$ & $\begin{array}{l}\text { Stagnant water } \\
\text { No aeration } \\
\text { Excessive algal growth }\end{array}$ & $\begin{array}{c}\text { Provides a sample with stagnant and } \\
\text { non-aerated water, by-products from } \\
\text { algal growth }\end{array}$ \\
\hline $\begin{array}{c}\text { Keroh River, Kepong } \\
\left(3^{\circ} 12^{\prime} 25.0^{\prime} \mathrm{N} 101^{\circ} 38 \text { '27.9'E) }\right.\end{array}$ & $\begin{array}{c}\text { Flowing water } \\
\text { Aerated } \\
\text { Polluted by nearby industries and } \\
\text { commercial businesses }\end{array}$ & $\begin{array}{c}\text { Provides an aerated water sample, } \\
\text { but polluted by nearby industries and } \\
\text { commercial business such as dumping } \\
\text { of the excess food by restaurants found } \\
\text { abundantly nearby }\end{array}$ \\
\hline $\begin{array}{l}\text { Household rice-rinsed water } \\
\left(3^{\circ} 07^{\prime} 38.0^{\prime \prime} \mathrm{N} 101^{\circ} 51^{\prime} 83.0^{\prime \prime} \mathrm{E}\right)\end{array}$ & $\begin{array}{l}\text { Obtained from washing rice grains } \\
\text { Washed with tap water }\end{array}$ & $\begin{array}{l}\text { Provides a sample with high content of } \\
\text { starch but minimal pollution }\end{array}$ \\
\hline
\end{tabular}

The initial data(s) was also obtained from the water sources prior to treatment by fruit or vegetable produced ecoenzymes to establish a baseline to be compared with to assess the effectiveness or impacts towards treating the water sources.

\section{Data analysis of vegetable and fruit eco-enzymes}

The initial concentrations of $\mathrm{Ca}^{2+}, \mathrm{K}^{+}, \mathrm{Na}^{+}$and $\mathrm{NO}_{3}{ }^{-}$within the waste fruit and vegetable produced enzymes were also measured in parts per million (ppm). The $\mathrm{pH}$ of the eco-enzymes was also measured and tabulated alongside the other parameters in Table 2. 
Table 2. Concentration (ppm) of ions present and the $\mathrm{pH}$ within the eco-enzyme solutions (control).

\begin{tabular}{|c|c|c|c|c|c|c|c|c|c|c|c|}
\hline \multirow{3}{*}{ Solution } & \multirow{3}{*}{ Composition } & \multicolumn{10}{|c|}{ Duration (day) } \\
\hline & & \multicolumn{2}{|c|}{ Day 1} & \multicolumn{2}{|c|}{ Day 2} & \multicolumn{2}{|c|}{ Day 3} & \multicolumn{2}{|c|}{ Day 4} & \multicolumn{2}{|c|}{ Day 5} \\
\hline & & Average & $\sigma$ & Average & $\sigma$ & Average & $\sigma$ & Average & $\sigma$ & Average & $\sigma$ \\
\hline \multirow{5}{*}{$\begin{array}{l}\text { Vegetable- } \\
\text { produced } \\
\text { eco-enzyme }\end{array}$} & $\mathrm{Ca}^{2+}(\mathrm{ppm})$ & 56.2 & 16.9 & 57.3 & 18.2 & 62.5 & 12.6 & 83.6 & 18 & 107.8 & 24.2 \\
\hline & $\mathrm{Na}^{+}(\mathrm{ppm})$ & 201.1 & 22.6 & 211.1 & 34.1 & 241.1 & 33.3 & 260 & 43.3 & 303.3 & 34.3 \\
\hline & $\mathrm{K}^{+}(\mathrm{ppm})$ & 1543.3 & 650.1 & 1556.7 & 265.9 & 1821.1 & 391.7 & 1855.6 & 332.1 & 2055.6 & 450.3 \\
\hline & $\mathrm{NO}_{3}^{-}(\mathrm{ppm})$ & 2472.2 & 274.7 & 2455.6 & 675.2 & 4656.7 & 531.6 & 5588.9 & 1083 & 3422.2 & 898.3 \\
\hline & $\mathrm{pH}$ reading & 5.1 & 0.1 & 5.1 & 0.13 & 5.01 & 0.15 & 5.2 & 0.17 & 5.24 & 0.14 \\
\hline \multirow{5}{*}{$\begin{array}{l}\text { Fruit-pro- } \\
\text { duced } \\
\text { eco-enzyme }\end{array}$} & $\mathrm{Ca}^{2+}(\mathrm{ppm})$ & 9.5 & 0.55 & 10.2 & 1.47 & 12.3 & 0.51 & 15.7 & 1 & 20.5 & 1 \\
\hline & $\mathrm{Na}^{+}(\mathrm{ppm})$ & 183.3 & 5.2 & 186.7 & 8.16 & 183.3 & 22.5 & 225 & 13.8 & 256.7 & 19.7 \\
\hline & $\mathrm{K}^{+}(\mathrm{ppm})$ & 926.7 & 10.3 & 931.7 & 17.2 & 1058.3 & 66.5 & 933.3 & 41.8 & 1098.3 & 111.4 \\
\hline & $\mathrm{NO}_{3}^{-}(\mathrm{ppm})$ & 85.5 & 9.35 & 87.2 & 11.05 & 135 & 15.2 & 143.2 & 25.4 & 135 & 13.8 \\
\hline & $\mathrm{pH}$ reading & 4.5 & 0.14 & 4.5 & 0.09 & 4.3 & 0.05 & 4.1 & 0.05 & 4.24 & 0.03 \\
\hline
\end{tabular}

Table 2 showed that the concentration of $\mathrm{Ca}^{2+}$ in the vegetable-produced eco-enzyme solution is much higher at $107.8 \mathrm{ppm}$ than the $\mathrm{Ca}^{2+}$ concentration in the fruit-produced eco-enzyme which was only $20.5 \mathrm{ppm}$. This is consistent with the data obtained from research conducted by Reid et al. [23], which compared four international food databases for the concentration of $\mathrm{Ca}^{2+}$ in foods for human consumption which included fruits and vegetables. High content of $\mathrm{Ca}^{2+}$ was due to the fermentation substrate used to produce eco-enzymes, which consists of predominantly green-leafy vegetables such as spinach which are known to naturally contain a high healthful source of $\mathrm{Ca}^{2+}$. According to Umar et al. [24] and Gupta et al. [25] Chenopodium album, Centella asiatica, Amaranthus tricolor and Trigonella foenum graecum. The green leafy vegetables (GLV) [25], spinach contains approximately $1 \mathrm{mg} / \mathrm{g} \mathrm{of} \mathrm{Ca}^{2+}$. Based on the findings, the $\mathrm{Ca}^{2+}$ concentration measured in fermented samples was much lower compared to the $\mathrm{Ca}^{2+}$ concentration reported from spinach (Table 2). This might because of oxalate content in the spinach that binds to $\mathrm{Ca}^{2+}$ which lower the $\mathrm{Ca}^{2+}$ concentration in the eco-enzymes as well as due to short fermentation duration [26]. This situation was supported Yang et al. [27], in which the same condition was observed in their experiment, where fermented carrots only provide 15 $\mathrm{mg} / 100 \mathrm{~g}$ of calcium.

In addition, the $\mathrm{Na}^{+}$concentration for vegetable produced eco-enzymes showed a higher concentration compared to that of fruit produced eco-enzymes. The vegetable produced eco-enzymes showed a gradually increase of $\mathrm{Na}^{+}$ concentration with a maximum of $303.2 \mathrm{ppm}$ at Day 5 whereas the maximum $\mathrm{Na}^{+}$concentration for fruits produced ecoenzymes was $256.7 \mathrm{ppm}$ at Day 5. According to researches done by Umar et al. [24] and Rahmatollah and Mahbobeh [28], with the objective to evaluate the nutritional contents of different species of spinach and carrots, it was found that different species of spinach contains about $135-550 \mathrm{mg} / 100 \mathrm{~g}$ which equates to $1350-5500 \mathrm{ppm}$ that was much higher than the reading obtained in this experiment which was only $303.3 \mathrm{ppm}$. Meanwhile, carrots are found to contain about $40 \mathrm{mg} / 100 \mathrm{~g}$ which is about $400 \mathrm{ppm}$ which was close to the concentration obtained from this experiment which was $256.7 \mathrm{ppm}$. This might be due to a short fermentation time of 1 week and locations from which the spinach and carrots were obtained [29].

Green leafy vegetables are known to be the major source of $\mathrm{NO}_{3}{ }^{-}$amongst food for human consumption, one such leafy green vegetable is spinach, known to have high amounts of $\mathrm{NO}_{3}^{-}$as $\mathrm{NO}_{3}^{-}$plays an important part in its growth and therefore has increased $\mathrm{NO}_{3}{ }^{-}$uptake by the plant [30-31]. Studies showed that spinach can accumulate $\mathrm{NO}_{3}^{-}$between the range of $185-300 \mathrm{mg} / 100 \mathrm{~g}$ which is $1845-3000 \mathrm{ppm}$, depending on the season and location of the sample during harvesting [32-33]. As for carrots, studies have shown that $\mathrm{NO}_{3}{ }^{-}$content in carrots are approximately between the range of $0.41-40 \mathrm{mg} / 100 \mathrm{~g}$, which around $4-400 \mathrm{ppm}$, this estimate is consistent with the data obtained from this experiment 
[29].

Production of eco-enzyme has an acidic nature due to carbohydrate being broken into volatile acids and organic acids [34]. This was observed in Table 2 where both eco-enzymes produced by vegetables and fruits were in an acidic condition within the range of $\mathrm{pH} 4-5 \pm 0.5$.

\subsection{Water samples treated by eco-enzyme}

Table 3 shows the concentration of the measured parameters in parts per million (ppm) of $\mathrm{Ca}^{2+}, \mathrm{Na}^{+}, \mathrm{K}^{+}, \mathrm{NO}_{3}{ }^{-}$ and the $\mathrm{pH}$ in river water samples from Keroh River, Menjalara lake and Household rise-rinsing sample treated with eco-enzymes. From this finding, $\mathrm{Ca}^{2+}, \mathrm{Na}^{+}, \mathrm{K}^{+}$and $\mathrm{NO}_{3}{ }^{-}$in all three water samples show significant influence by the fermented vegetable and fruits waste. In addition, $\mathrm{NO}_{3}{ }^{-}$in all treatment show dramatically reduced by the fermented vegetable and fruits waste exclude river and lake water treated by vegetable waste. This reduction could be due to the presence of nitrate reductase which catalyzes the reaction of reducing nitrate $\left(\mathrm{NO}_{3}{ }^{-}\right)$to nitrite $\left(\mathrm{NO}_{2}{ }^{-}\right)$which is then further reduced to ammonium $\left(\mathrm{NH}_{4}^{+}\right)$by various nitrate reductases that are produced by a number of bacteria species [35]. Examples of such bacteria include Escherichia coli, Paracoccus denitrificans and Achromobacter xylosoxidans, however, there are more species of bacteria that are able to secrete nitrate reductase [36]. In river and lake water, the microbial consortium in fermented vegetable waste, might enhance the nitrification cycle, and convert ammonia to $\mathrm{NO}_{3}{ }^{-}$.

Table 3. Water quality monitoring based on $\mathrm{Ca}^{2+}, \mathrm{Na}^{+}, \mathrm{K}^{+}, \mathrm{NO}_{3}{ }^{-}$and $\mathrm{pH}$ after 5 days of treatment using eco-enzyme harvesting from fermented vegetable and fruits

\begin{tabular}{cccccccc}
\hline & & \multicolumn{5}{c}{ Water samples } \\
\cline { 3 - 8 } Eco-enzyme & Composition & \multicolumn{2}{c}{ River } & \multicolumn{2}{c}{ Lake } & \multicolumn{2}{c}{ Rice-rinsing Water } \\
\cline { 3 - 8 } & & Before & After & Before & After & Before & After \\
\cline { 3 - 8 } & Calcium ions (ppm) & $29.3 \pm 1.1$ & $75.7 \pm 4.5$ & $25.3 \pm 3.2$ & $53.4 \pm 7.0$ & $21.3 \pm 2.3$ & $73.9 \pm 6.9$ \\
& Sodium ions (ppm) & $29.3 \pm 2.3$ & $43.0 \pm 2.7$ & $7.33 \pm 1.2$ & $16.6 \pm 1.5$ & $22.0 \pm 3.7$ & $27.4 \pm 9.7$ \\
Vegetable waste & Potassium ions (ppm) & $6.7 \pm 1.5$ & $67.1 \pm 8.3$ & $4.3 \pm 0.6$ & $64.9 \pm 13.1$ & $24.7 \pm 0.6$ & $95.1 \pm 14.0$ \\
& Nitrate ions (ppm) & $1383.3 \pm 76.4$ & $2056.7 \pm 166.1$ & $456.4 \pm 26.6$ & $647.6 \pm 353.3$ & $440.6 \pm 50.3$ & $204 \pm 115.1$ \\
& pH & $3.97 \pm 1.18$ & $3.90 \pm 0.07$ & $4.33 \pm 0.02$ & $3.82 \pm 0.06$ & $4.69 \pm 0.06$ & $3.97 \pm 0.05$ \\
& Calcium ions (ppm) & $29.3 \pm 1.1$ & $45.7 \pm 5.6$ & $25.3 \pm 3.2$ & $16.2 \pm 2.9$ & $21.3 \pm 2.3$ & $35.5 \pm 2.4$ \\
& Sodium ions (ppm) & $29.3 \pm 2.3$ & $55.5 \pm 1.4$ & $7.33 \pm 1.2$ & $14.7 \pm 10.1$ & $22.0 \pm 3.7$ & $27.5 \pm 2.2$ \\
& Potassium ions (ppm) & $6.7 \pm 1.5$ & $25.8 \pm 2.0$ & $4.3 \pm 0.6$ & $21.0 \pm 2.8$ & $24.7 \pm 0.6$ & $\pm 55.8 \pm 5.4$ \\
& Nitrate ions (ppm) & $1383.3 \pm 76.4$ & $16.8 \pm 1.5$ & $456.4 \pm 26.6$ & $14.7 \pm 1.8$ & $440.6 \pm 50.3$ & $\pm 34.2 \pm 16.5$ \\
& pH & $3.97 \pm 1.18$ & $4.52 \pm 0.17$ & $4.33 \pm 0.02$ & $3.76 \pm 0.15$ & $4.69 \pm 0.06$ & $\pm 4.08 \pm 0.11$ \\
\hline
\end{tabular}

E. coli is known to be found in various food waste and is also as common bacterial population found on animal faeces [37]. It is possible that since the fruit-produced eco-enzyme was fermented using the native bacterial population present within the fruit, bacteria that have nitrate reductase production such as E. coli was present. Hence, the bacteria proceeded to produce abundant amounts of nitrate reductase which was then inoculated with the water sample that contained $\mathrm{NO}_{3}^{-}$which then further reduced the $\mathrm{NO}_{3}{ }^{-}$into $\mathrm{NH}_{4}{ }^{+}$and was released to the surrounding as deionized ammonia, which explains the foul odour associated with the samples [38]. As for the vegetable-produced eco-enzyme treated waters, $\mathrm{NO}_{3}{ }^{-}$was increased compared to the fruit-produced eco-enzyme, this might be due to the fact that the vegetables were fermented with Saccharomyces cerevisiae commonly known as baker's yeast. The saccharomyces genus is not known to produce nitrate reductase, this genus typically is not able to use $\mathrm{NO}_{3}{ }^{-}$as a sole source of nitrogen for metabolism. Due to the lack of nitrate reductase, the concentration of $\mathrm{NO}_{3}^{-}$in vegetable-produced eco-enzyme 
treated water samples increases rather than reduced [39].

The data obtained from other measured parameters such as $\mathrm{Ca}^{2+}, \mathrm{Na}^{+}$and $\mathrm{K}^{+}$shows that there is a significant improvement in the quality of water after 5 days of treatment. Since $\mathrm{Ca}^{2+}, \mathrm{Na}^{+}$and $\mathrm{K}^{+}$are members of the metallic family on the periodic table, enzymes are not known to have any reaction that can remove the metal ions from the wastewater from one form to another. Metal ions are more known to bind with proteins to form complexes, proteins such as haemoglobins contain iron that ensures the binding of oxygen for cellular transport, other usages of metal ions in enzymes are to act as co-factors to catalyze other chemical reactions [40]. Hence, it is no surprise that the ecoenzymes produced from the waste fruits and vegetables did not pose an impact on the concentration of metal ions in the water samples. However, it is possible to exploit the protein-metal binding properties as a method to remove unwanted metal ions by using proteins or bacteria which naturally uptakes metal ions via bioaccumulation [41]. From the data analysis, it was also observed that all the water samples displayed an acidic nature. This acidic environment might able to enhance the activity of microbes to produce eco-enzyme and also to increase their metabolism in the nitrification cycle. Rasit and Chee Kuan [34], also observed this characteristic of waste-derived enzymes in their experiment of using garbage enzymes to pretreat palm oil mill effluent (POME).

The study also showed that metal ions such as $\mathrm{Ca}^{2+}, \mathrm{Na}^{+}$and $\mathrm{K}^{+}$was overall not affected in terms of reduction of the ions themselves. This could potentially be due to the natural properties of enzymes that do not react with the metal to form a secondary product but more so binding with the metal ions to form a complex commonly termed metalloproteins, in order to perform catalytic reactions that are specific to the enzyme itself [42]. Other than not reducing the metal ion components present within the wastewater, the eco-enzymes further contributed to the increase of metal ions within the treated wastewater. The potential reason for this could be due to the natural composition of the substrates used for fermentation. The substrates used for fermentation were predominantly composed of spinaches and carrots which both are known to have moderate to high levels of $\mathrm{Ca}^{2+}, \mathrm{Na}^{+}$and $\mathrm{K}^{+}$[24-25]. According to Regina et al. [43], high levels of $\mathrm{Ca}^{2+}, \mathrm{Na}^{+}$and $\mathrm{K}^{+}$were also observed in river water treated with mudball or water hyacinth, respectively. Thus, the addition of fermented food enriches the microbial consortium that able to increase the level of water minerals.

From the study, it was also observed that the $\mathrm{pH}$ of the eco-enzymes were both acidic either for the vegetableproduced eco-enzyme or the fruit-produced eco-enzyme. This is due to the carbohydrate content that is abundantly present in vegetables and fruits [44]. Similar studies about eco-enzymes show that the fermentation broth containing the eco-enzymes is indeed acidic in nature due to the carbohydrate content present within in fruits and vegetables as the carbohydrate content is metabolized into volatile acids and organic acids [34]. As stated by Sethupathy et al. [45], the optimal condition of treatment is in $\mathrm{pH} 6$ for treatment 30 days. Thus, this suggested that the duration of treatment should be one of the parameters that will affect the findings.

With the emphasis on SDGs and environmental conservation worldwide, the community in each society should aware of on the benefit of fully utilize the biowaste, including food and vegetable waste. Eco-enzyme produced from the fermented biowaste, show potential in wastewater treatment with the help of a natural microbial consortium. Thus, a sustainable wastewater treatment can be design to effectively reduce the water pollution [43, 46-47].

\section{Conclusion}

The present study showed that fruit-produced eco-enzyme with a native bacterial population as an agent for fermentation showed a more promising result compared to eco-enzymes produced from the fermentation of vegetables. An improvement that can be done in the future would be prolonging the treatment duration to assess the long-term effect of the treatment on the wastewater as well as experimentation with different concentration of eco-enzymes to potentially reduce the introduction of excess metal ions into treated wastewaters.

\section{References}

[1] Mirmohamadsadeghi S, Karimi, K, Tabatabaei, M, Aghbashlo M. Biogas production from food wastes: A review on recent developments and future perspectives. Bioresource Technology Reports. 2019; 7: 100202.

[2] Chai L. The river water quality before and during the Movement Control Order (MCO) in Malaysia. Case Studies 
in Chemical and Environmental Engineering. 2020; 2: 100027.

[3] Bagherzadeh M, Inamura M, Jeong H, Publishing O. Food waste along food value chains. OECD Food, Agriculture and Fisheries Papers. 2014; 71: 29.

[4] De Laurentiis V, Corrado S, Sala S. Quantifying household waste of fresh fruit and vegetables in the EU. Waste Management. 2018; 77: 238-251.

[5] Kathirvale S, Muhd Yunus MN, Sopian K, Samsuddin AH. Energy potential from municipal solid waste in Malaysia. Renewable Energy. 2004; 29(4): 559-567.

[6] Mohd Sharif N. Amount of food wasted by Malaysians enough to feed 12 million people a day. New Straits Times. 2018. Available from: https:/www.nst.com.my/news/nation/2018/12/441882/amount-food-wasted-malaysiansenough-feed-12-million-people-day [Accessed 3rd April 2021].

[7] Norsa'adah B, Salinah O, Naing N, Sarimah A. Community health survey of residents living near a solid waste open dumpsite in Sabak, Kelantan, Malaysia. International Journal of Environmental Research and Public Health. 2020; 17(1): 311 .

[8] Omran A, Mahmood A, Aziz H. Current practice of solid waste management in malaysia and its disposal. Environmental Engineering and Management Journal. 2007; 6(4): 295-300.

[9] Behera SK, Park JM, Kim KH, Park HS. Methane production from food waste leachate in laboratory-scale simulated landfill. Waste Management. 2010; 30(8-9): 1502-1508.

[10] Kibria G. Food waste impacts on climate change and water resources. A part of a research project on communitybased environmenal and sustainability education model in Australia. 2017. Available from: https://www. researchgate.net/publication/316547640_Food_Waste_Impacts_on_Climate_Change_Water_Resources [Accessed 18th April 2021].

[11] Dhiman S. Eco-enzyme-a perfect house-hold organic cleanser. International Journal of Engineering Technology, Management and Applied Sciences. 2017; 5(11): 19-23.

[12] Kerkar S, Salvi S. Application of eco-enzyme for domestic waste water treatment. International Journal for Research in Engineering Application \& Management. 2020; 5(11): 114-116.

[13] Rasit N, Lim HF, Ab Karim Ghani WAW. Production and characterization of eco-enzyme produced from tomato and orange wastes and its influence on the aquaculture sludge. International Journal of Civil Engineering and Technology. 2019; 10(3): 967-980.

[14] Ahmed F, Siwar C, Begum RA. Water resources in Malaysia: Issues and challenges. Journal of Food, Agriculture and Environment. 2014; 12(2): 1100-1104.

[15] Lam S, Nguyen-Viet H, Tuyet-Hanh TT, Nguyen-Mai H, Harper S. Evidence for public health risks of wastewater and excreta management practices in Southeast Asia: A scoping review. International Journal of Environmental Research and Public Health. 2015; 12(10): 12863-12865.

[16] Maximillian J, Brusseau M, Glenn E, Matthias A. Pollution and environmental perturbations in the global system. Environmental and Pollution Science. 2019. p.457-476. Available from: https://www.sciencedirect.com/science/ article/pii/B9780128147191000252.

[17] Kamarudzaman AN, Voon KF, Aziz RA, Jalil MFA. Study of point and non point sources pollution-A case study of Timah Tasoh Lake in Perlis, Malaysia. International Conference on Environmental and Computer Science. 2011. p.19. Available from: https://www.academia.edu/2031407/Study_of_Point_and_Non_Point_Sources_Pollution_A_ Case_Study_of_Timah_Tasoh_Lake_in_Perlis_Malaysia [Accessed 18th April 2021].

[18] Holeton C, $\bar{C}$ hambers $\overline{\text { PA }}$, Grace, L. Wastewater release and its impacts on Canadian waters. Canadian Journal of Fisheries and Aquatic Sciences. 2011; 68(10): 1836-1859.

[19] Edgerton MD. Increasing crop productivity to meet global needs for feed, food, and fuel. Plant Physiology. 2009; 149: 7-13.

[20] Ayoub AT. Fertilizers and the environment. Nutrient Cycling in Agroecosystems. 1999; 55(2): 117-121.

[21] Gold A, Sims J. Eutrophication. Encyclopedia of Soils in the Environment. 2005. p.486-494.

[22] Khan M, Mohammad F. Eutrophication: Challenges and solutions. Eutrophication: Causes, Consequences and Control. 2013. p.1-15.

[23] Reid MMW, Verbrugghe A, Shoveller AK. Concentrations of calcium, phosphorus, and Vitamin D in human foods are not different among 4 food databases. Canadian Veterinary Journal. 2018; 59(2): 174-177.

[24] Umar KJ, Hassan LG, Dangoggo SM, Ladan MJ. Nutritional composition of water spinach (Ipomoea aquatica Forsk) leaves. Journal of Applied Sciences. 2007; 7(6): 803-809.

[25] Gupta S, Gowri BS, Lakshmi AJ, Prakash J. Retention of nutrients in green leafy vegetables on dehydration. Journal of Food Science and Technology. 2013; 50(5): 918-925.

[26] Bong W, Vanhanen L, Savage G. Addition of calcium compounds to reduce soluble oxalate in a high oxalate food 
system. Food Chemistry. 2017; 221: 54-57.

[27] Yang J, Punshon T, Guerinot M, Lou Hirschi KD. Plant calcium content: Ready to remodel. Nutrients. 2012; 4(8): 1120-1136.

[28] Rahmatollah R, Mahbobeh R. Mineral contents of some plants used in Iran. Pharmacognosy Research. 2010; 2(4): 267-270.

[29] Sharma KD, Karki S, Thakur NS, Attri S. Chemical composition, functional properties and processing of carrot-A review. Journal of Food Science and Technology. 2012; 49(1): 22-32.

[30] Pate JS. Uptake, assimilation and transport of nitrogen compounds by plants. Soil Biology and Biochemistry. 1973; 5(1): 109-119.

[31] Yamasaki H, Watanabe NS. Dynamics of nitrite content in fresh spinach leaves: evidence for nitrite formation caused by microbial nitrate reductase activity. Journal of Nutrition \& Food Sciences. 2017; 7: 1.

[32] Santamaria P, Elia A, Serio F, Todaro E. A survey of nitrate and oxalate content in fresh vegetables. Journal of the Science of Food and Agriculture. 1999; 79(13): 1882-1888.

[33] Brkić D, Bošnir J, Bevardi M, Bošković AG, Miloš S, Lasić D, et al. Nitrate in leafy green vegetables and estimated intake. African Journal of Traditional, Complementary, and Alternative Medicines: AJTCAM. 2017; 14(3): 31-41.

[34] Rasit N, Chee Kuan O. IOP conference series: earth and environmental science investigation on the influence of bio-catalytic enzyme produced from fruit and vegetable waste on palm oil mill effluent related content annealing optimization in the process of making membrane PSF19\%DMFEVA2 for wastewater treatment of palm oil mill effluent a a said and mustafa-start-up treatment of palm oil mill effluent investigation on the influence of biocatalytic enzyme produced from fruit and vegetable waste on palm oil mill effluent. IOP Conference Series: Earth and Environmental Science. 2018; 140: 12015.

[35] Moreno-Vivián C, Cabello P, Martínez-Luque M, Blasco R, Castillo F. Prokaryotic nitrate reduction: Molecular properties and functional distinction among bacterial nitrate reductases. Journal of Bacteriology. 1999; 181(21): 6573-6584.

[36] Brittain T, Blackmore R, Greenwood C, Thomson AJ. Bacterial nitrite-reducing enzymes. European Journal of Biochemistry. 1992; 209(3): 793-802.

[37] Avery LM, Killham K, Jones DL. Survival of E. coli O157:H7 in organic wastes destined for land application. Journal of Applied Microbiology. 2005; 98(4): 814-822.

[38] Rezagama A, Hibbaan M, Arief Budihardjo M. Ammonia-nitrogen (NH 3-N) and ammonium-nitrogen (NH 4 $+-\mathrm{N})$ equilibrium on the process of removing nitrogen by using tubular plastic media. Journal of Materials and Environmental Sciences. 2017; 8(S): 4915-4922.

[39] Siverio JM. Assimilation of nitrate by yeasts. FEMS Microbiology Reviews. 2002; 26(3): 277-284.

[40] Andreini C, Bertin I, Cavallaro G, Holliday GL, Thornton JM. Metal ions in biological catalysis: from enzyme databases to general principles. Journal of Biological Inorganic Chemistry. 2008; 13: 1205-1218.

[41] Diep P, Mahadevan R, Yakunin AF. Heavy metal removal by bioaccumulation using genetically engineered microorganisms. Frontiers in Bioengineering and Biotechnology. 2018; 6: 157.

[42] Banaszak LJ. Metal ions bound to proteins. Foundations of Structural Biology. 2000; 137-147.

[43] Regina LZL, Teo SS. Designing prototype micro-technology for sustainable management of natural water resource. International Journal of Marine Biological Research. 2019; 4(20): 1-15.

[44] Slavin J, Carlson J. Nutrient information carbohydrates 1. American Society for Nutrition. 2014; 5(6): $760-761$.

[45] Sethupathy A, Teja GR, Arun C, Sivashanmugam P. Study on optimization of co-digestion process parameters for enhancing biohydrogen production using response surface methodology. Journal of Energy Sources, Part A: Recovery, Utilization and Environmental Effects. 2018; 40(14): 1753-1764.

[46] Ho SW, Cheung KK, Fung WC. Sustainable wastewater treatment-ways to achieve energy neutrality. HKIE Transactions. 2014; 21(4): 240-252.

[47] Ho YM, Ling LK, Manaf LA. Garbage enzyme as a solution to waste minimization. From Sources to Solution. 2014. p.347-350. 